$$
1+33111--517
$$

UCRL- 89475

PREPRINT

\title{
Post Emplacement Erivironment of Waste Packages
}

\author{
K. G. Knauss \\ V. M. Oversby \\ T. J. Wolery
}
Materials Research Society Symposium
Boston, MASS
November 14-17, 1983

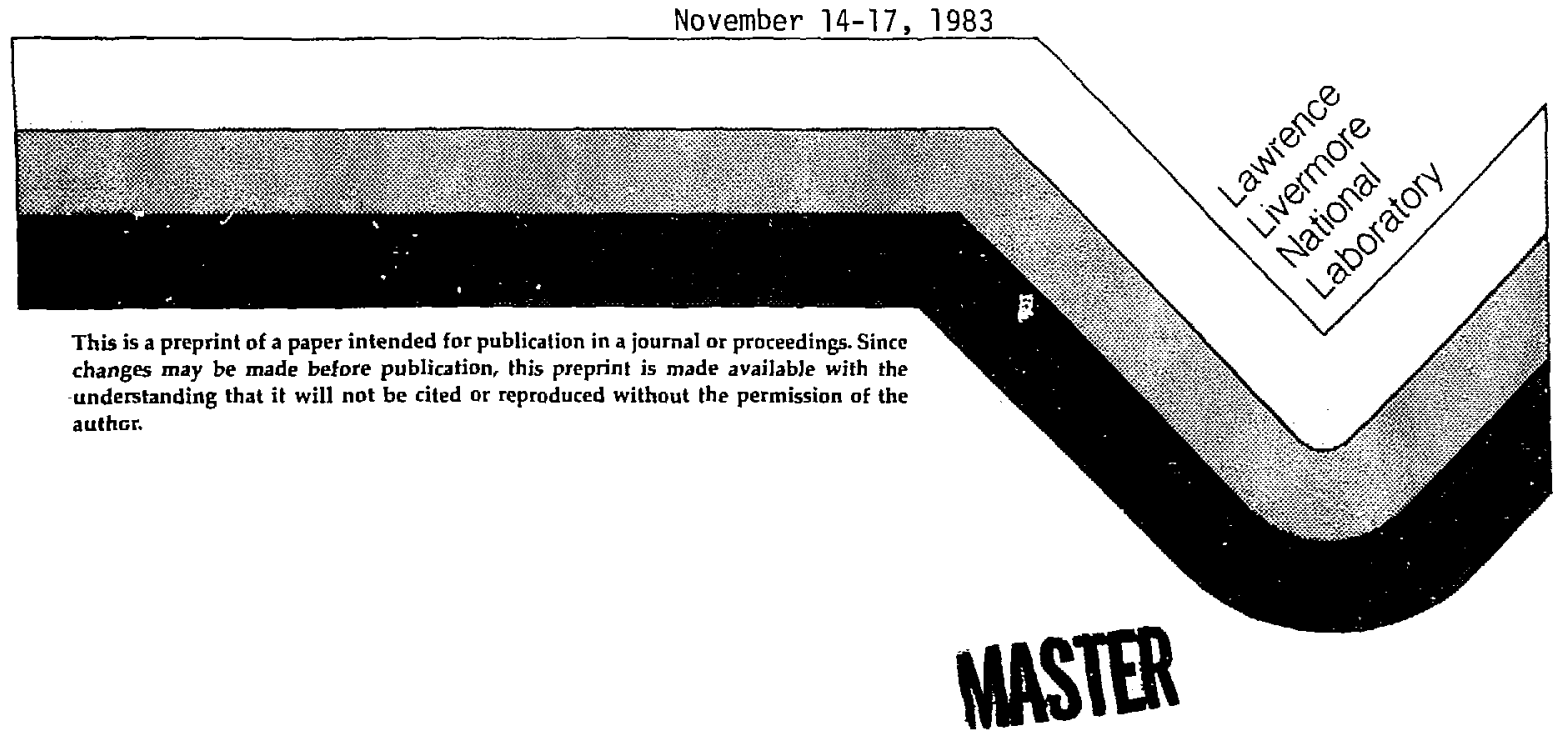




\section{DISCLAIMER}

This report was prepared as an account of work sponsored by an agency of the United States Government. Neitlier the United States Government nor any agency thereof, nor any of their employees, makes any warranty, express or implied, or assumes any legal liability or responsibility for the accuracy, completeness, or usefuiness of any information, apparatus, product, or process disclosed, or represents that its use would not infringe privately owned rights. Reference herein to any specific commercial product, process, or service by trade name, trademark, munufacturer, or otherwise does not necessarily constitute or imply its eudorsement, recommendation, or favoring by the United States Government or any agency thereof. The views and opinians of authors expressed herein do not necessarily state or reflect those of the United Statec Government or any agency therenf. 
K. G. KNAUSS, V. M. GVERSBY, and T. J. WOLERY

Department of Earth Sciences, Lawrence Livermore National Laboratory, P.0. Box 808, Livermore, CA 94550

\section{ABSTRACT}

Experiments nave been conducted as part of the Nevada Nuclear Waste Storage Investigations Project to determine the changes in water chemistry due to reaction of the Topopan Spring tuff with natural groundwater at temperatures up to $150^{\circ} \mathrm{C}$. The reaction extent has been investigated as a function of rock-to-water ratio, temperature, reaction time, physical state of the samples, and geographic location of the samples witnin the tuff unit. Results of these experiments will be used to provide information on the water chemistry to be expected if a high level waste repository were to be constructed in the Topopan Spring tuff.

\section{INTRODUCTION}

The initial response of the near field environment to the heat generated by the emplacement of nuclear waste packages is an increase in temperature which causes the partially saturated country rock to dry out. Following the initial thermal pulse the rock will cool and liquid water will gradualiy return to the vicinity of the waste packages. As the water passes through neated rock it will react with the rock and change in chemical composition. To determine the chemistry of the water which will be available for interaction with tne waste packages we have investigated the changes in chemistry resulting from the equilibration of $J-13$ well water with Topopah Spring tuff a's a function of rock-to-water ratio, temperature, reaction time, physical state of the samples, and geograpnic location of the rock within the prospective repository location. Results of the experiments have been compared with predictions based on the EQ3/6 geochemical modeling code [1].

\section{EXPERIMENTS USING CRUSHED TUFF}

Two matrix experiments were conducted using Topopah Spring tuff crushed to less ihan 100 mesh and J-13 well water. Detailed experimental procedures and results are given in Oversby [2]. The tests were conducted in teflon containers (Parr acid digestion bombs). The test matrix at $150^{\circ} \mathrm{C}$ used sample weights of $0.2,0.4$, and $0.8 \mathrm{~g}$ of rock equiliorated with $12 \mathrm{ml}$ of $\mathrm{J}-13$ water for $1,2,4,8,16,31$ and 48 days. The $90^{\circ} \mathrm{C}$ matrix used larger reaction vessels, so sample sizes were scaled up to duplicate the surface area of rock to solution volume ratios used in the $150^{\circ} \mathrm{C}$ matrix. The $90^{\circ} \mathrm{C}$ matrix used rock weights of $0.4,0.8,1.6$, and 3.2 g equilibrated for $1,3,6,12,24,36,48,60$ and 72 days with 48 ml of $3-13$ water.

The rock samples which were used were obtained from a surface outcrop at Fran Ridge, slightly east of Yucca Mountain. Previous experience with rock-water hydrothermal experiments using Bullfrog tuff showed that surface outcrop samples contain easily soluble material which should be removed before conducting the equilibration experiments [3]. All samples used in this study were pretreated by shaking for two minutes at room temperature with J-13 water. Figure l shows data for $\mathrm{SO}_{\overline{4}}, \mathrm{NO}_{\overline{3}}$, and $\mathrm{Cl}^{-}$for solutions from this rinse (RTS). To ensure that all easily 
soluble material had been removed, the samples were equilibrated overnight at the reaction temperature with fresh J-13 water (Sample number 0-1, Figure 1). This two step pretreatment was applied to all samples; thus, data for 4 days at $150^{\circ} \mathrm{C}$ means pretreatment followed by four days of equilibration with fresh $\mathrm{J}-13$ water.

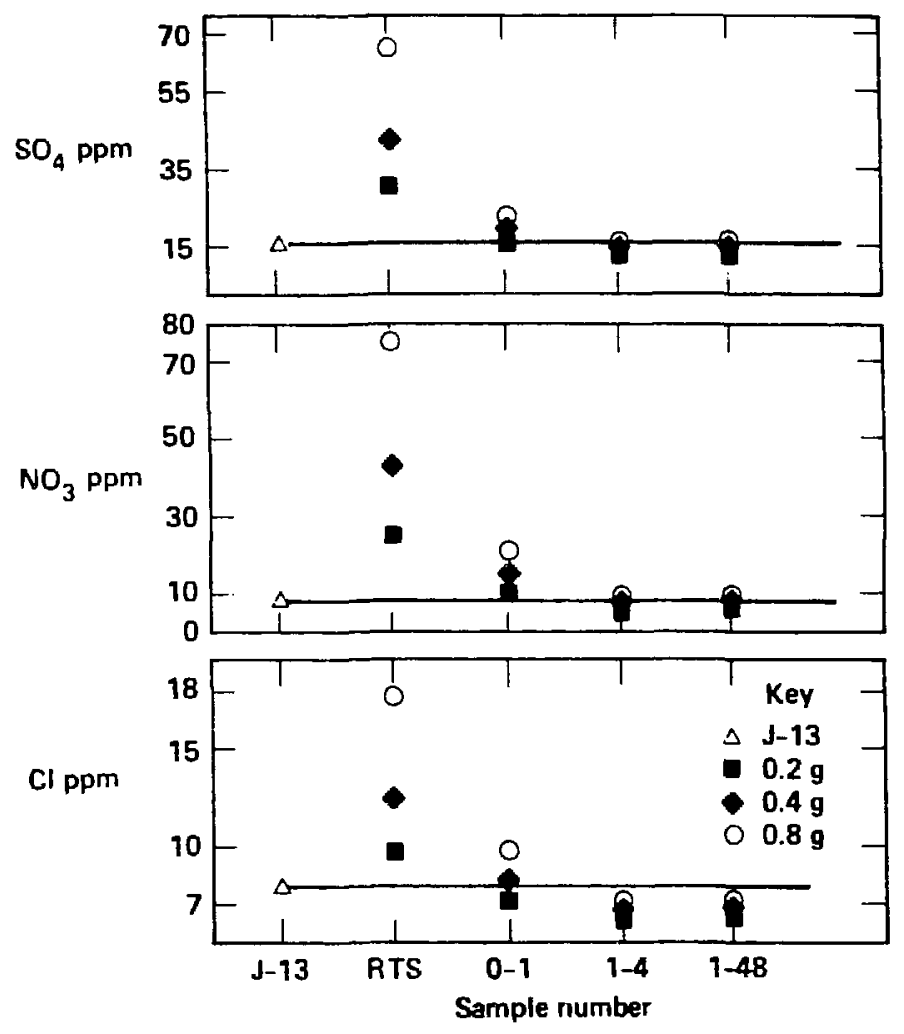

Fig. 1. Data for pretreatment solutions and fuur day and 48 day equilibration of Topopan Spring tuff with J-13 water at $150^{\circ} \mathrm{C}$. Data for pretreatment solutions are the average of analyses for all samples of the given sample weight.

Under expected repository conditions in the unsaturated zone, liquid water will not generally exist at temperatures higher than $95^{\circ} \mathrm{C}$, the unconfined boiling point of water at the repository level. Thus, the $90^{\circ} \mathrm{C}$ data discussed below are the most relevant to general repository conditions. The $150^{\circ} \mathrm{C}$ data were collected to obtain information on raction kinetics. They are also relevant to small amounts of water held in pores by capiliary forces; this water could be liquid at somewhat higher temperatures than the unconf ined boiling point.

Concentrations of $\mathrm{F}^{-}, \mathrm{Cl}^{-}, \mathrm{NO}_{\overline{3}}, \mathrm{SO}_{\overline{4}}$ and carbonate alkalinity were measured on ail samples. There were no significant changes in concentration due to reaction of $\mathrm{J}-13$ water يith the rock except in the case of alkalinity. J-13 carbonate alkal inity is 2.16 meq/1, which corresponds to $132 \mathrm{ppm}$ when calculated as $\mathrm{HCO}_{3}$.

Reaction at $90^{\circ} \mathrm{C}$ reduced alkalinity to approximately $1.8 \mathrm{meq} / 1$ (110 ppm) 
and reaction at $150^{\circ} \mathrm{C}$ reduced alkalinity to approximately 1.5 meq/1 (92 ppm). Samples of $J-13$ water heated witnout rock (J-1? blanks) showed somewhat greater reduction in alkalinity. Most oi the reduction in alkalinity can be correlated with a decrease in $\mathrm{Ca}$ and $\mathrm{Mg}$; however, especially in the case of tne blanks, there must also be sonic loss of $\mathrm{CO}_{2}$ to the teflon container.

Figure 2 shows some of the experimental dat 3 for $\mathrm{Ca}$ and $\mathrm{Al}$ at $90^{\circ} \mathrm{C}$ and $150^{\circ} \mathrm{C}$. The decrease in $\mathrm{Ca}$ is greater at the nigher temperature, as would be expected from the retrograde solubility of $\mathrm{CaCO}_{3}$. The precipitation reaction is slow, especially at $90^{\circ} \mathrm{C}$. Magnesium, which is $1.8 \mathrm{ppm}$ in $\mathrm{J}-13$ water, precipitates faster than $\mathrm{Ca}$, and is enricned in the centers of the euhedral calcite crystals which are found on the surface of reacted core wafers. Aluminum concentrations at $150^{\circ} \mathrm{C}$ rise on reaction with the tuff and then slowly decrease. This appears to be supersaturation due to colloid formation, followed by slow coagulation. The degree of supersaturation at $90^{\circ} \mathrm{C}$ is much less than at $150^{\circ} \mathrm{C}$, suggesting reduced importance of colloids at the lower temperature.

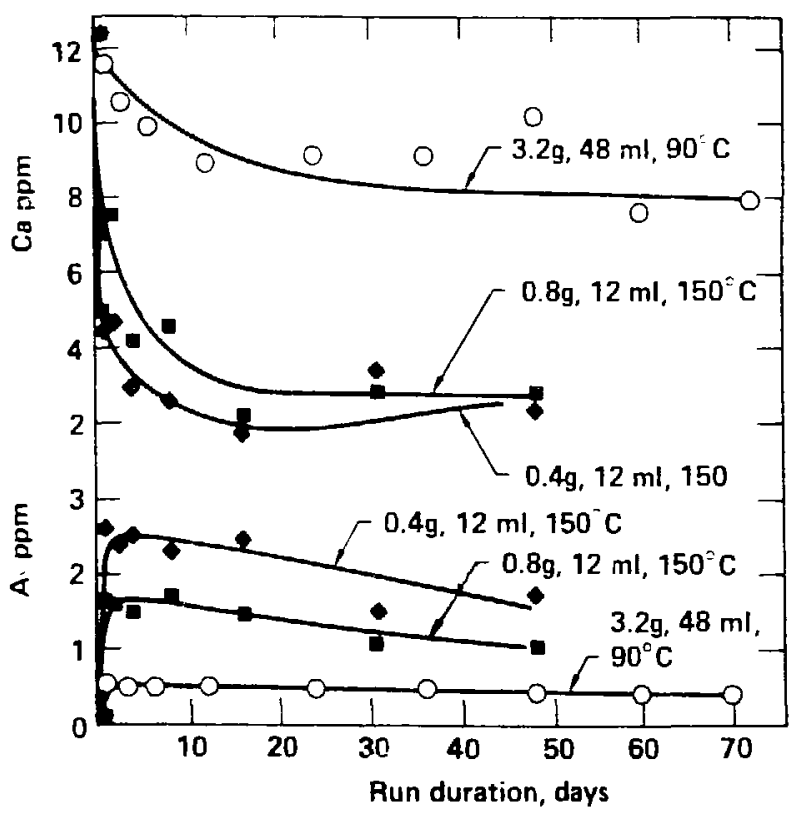

Fig. 2 Calcium and aluminum cuncentrations versus reaction time for reaction of pretreated Topopan Spring tuff with $\mathrm{J}-13$ water.

Silicon in solution increases slowly due to dissolution of quartz and cristobalite. Data are shown in Fig. 3 for a single rock/water ratio vs. reaction time. The solubility of silica is much higher at $150^{\circ} \mathrm{C}$ than at $90^{\circ} \mathrm{C}$, and appears to be controlled by cristobalite ratner than by quartz. The $\mathrm{pH}$ of the solutions, 8.5 at $90^{\circ} \mathrm{C}$ and 9.0 at $150^{\circ} \mathrm{C}$, is somewhat nigher than that predicted based on modeling calculations for the observed silica. This is especially true in the case of J-13 blanks which have only 20 to $25 \mathrm{ppm} 5 \mathrm{i}$. The high pH is attributed to loss of $\mathrm{CO}_{2}$ to the teflon. This is confirmed by the results of gold bag autoclave experiments (discussed below) which give final $\mathrm{pH}$ at $150^{\circ} \mathrm{C}$ of approximately 7. 


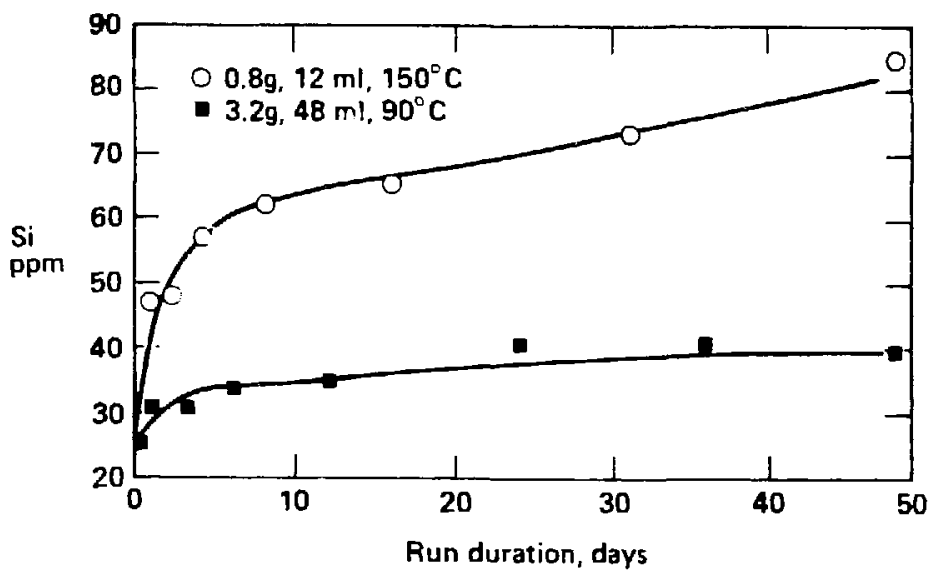

Fig. 3 Silicon concentration in solution for reaction of pretreated Topopah Spring tuff with J-13 water.

Sodium concentrations in solution after reaction are essentially the same as the J-13 starting values at both temperatures. Potassium shows an increase from $5.3 \mathrm{ppm}$ to values between 7 and $10 \mathrm{ppm}$; the value depends on the ratio of rock to water which suggests that the increase is due to the incomplete removal of the original soluble phase.

In order to estinate the degree of variability of solution chemistry as a function of position at Yucca Mountain we have used Topopan Spring tuff samples selected from the appropriate depth interval from three vertical drill holes (Gl, GA and GU3) and one horizontal air drilled hole (HI) at Fran Ridge. The solution concentrations after reaction for 64 days at $150^{\circ} \mathrm{C}$ are given in $\mathrm{Figure} 4$. The sample number gives the distance in feet from the surface at which the sample existed in situ. None of these samples showed the presence of any readily soluble salt material. This is especially significant in the case of the air orilled Fran Ridge samples. As a result of this data, we do not expect that we will encounter large amounts of soluble anion material at the :epository horizon. Solution data for these samples is very similar for all samples except for GU3-1072 Ft. which shows clear evidence of precipitation of a silicate pnase (Na is also low for this sample) and for two samples which are somewhat low in Si. The main difference between these samples and those discussed previously is in the $K$ concentrations. Other data for shorter reaction times is similar to that for the Fran Ridge outcrop material which indicates the slow precipitation of $K$ from solution in the. case of the eA lay icalluil times.

\section{EXPERIMENTS USING CORE WAFERS}

In order to investigate the water chemistry changes due to surface area variation and to sample preparation effects, as well as to determine the changes in primary solid phase chemistry and the distribution and chemistry of secondary phases, polished core wafers of Topopah Spring tuff were reacted with $\mathrm{J}-13$ water. Detailed experimental procedures are given in Knauss and Beiriger [4]. The tests were run at $150^{\circ} \mathrm{C}$ in large Parr bombs for periods of up to 4 months. The 5 amples were not pretreated to remove soluble material; however, large amounts of water were used in the 


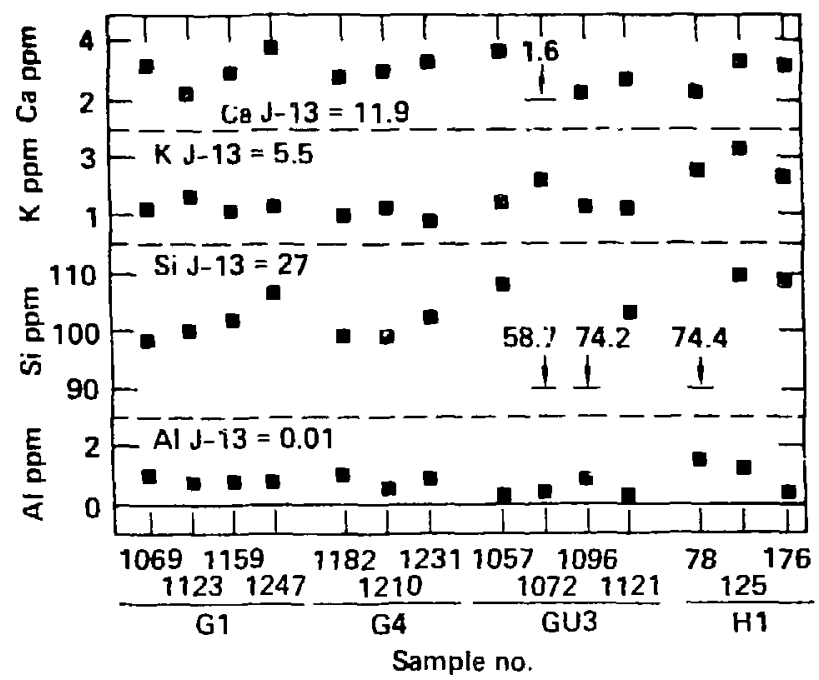

Fig. 4. Solution concentrations for drill core samples of Topopah Spring tuff reacted witin J-13 water for 64 days at $150^{\circ} \mathrm{C}$.

preparation of the wafers whicin effectively removes most of the readily soluble material. Experiments were run with wafers fully submerged in J-13 water (samples 1-4) and with wafers subjected to water saturated air (using J-13 water in limited quantities to produce the saturation). Samples 5-8 were the water saturated air runs.

Table I gives data for cations in solution, weight loss by the core wafer, ana $\mathrm{pH}$ as well as initial concentrations in J-13 water. The data for submerged samples are in excellent agreement with the resuits on crusned tuff samples except for $\mathrm{Al}$ and $\mathrm{Si}$. The crushed tuff experiments gave higner Al; these samples were rolled during the reaction period, which may have stabilized colloidal material in suspension. The higher si concentrations in the core wafers is due to the longer reaction time; there may also be a small amount of "glassy" material formed during the polishing of the core wafers prior to reaction [3].

Table I Solution data for core wafer experiments at $150^{\circ} \mathrm{C}$ in ppm

$\begin{array}{lccccccccc}\text { CW\# } & \text { Time }(d) & \text { Al } & \text { Si } & \text { Ca } & K & M g & \mathrm{Na} & \mathrm{pH} & W \mathrm{~T} \text {. loss } \\ 1 & 13.8 & 0.54 & 87.2 & 4.14 & 11.9 & 0.03 & 46.5 & 7.52 & 1.15 \\ 2 & 27.8 & 0.44 & 102 . & 3.84 & 9.0 & 0.05 & 47.5 & 8.06 & 1.38 \\ 3 & 55.8 & 0.37 & 119 . & 3.36 & 8.3 & 0.01 & 47.6 & 8.51 & 1.40 \\ 4 & 112.7 & 0.36 & 132 . & 4.24 & 7.1 & 0.01 & 61.0 & 8.70 & 1.44 \\ 5 & 13.8 & 0.00 & 25.2 & 7.10 & 4.8 & 0.29 & 44.3 & 7.35 & 0.09 \\ 6 & 27.8 & 0.00 & 28.5 & 6.27 & 7.6 & 0.26 & 49.7 & 7.35 & 0.11 \\ 7 & 54.8 & 0.02 & 27.7 & 5.68 & 6.4 & 0.17 & 48.9 & 7.40 & 0.10 \\ 8 & 111.7 & 0.00 & 35.7 & 6.16 & 7.0 & 0.04 & 58.5 & 8.50 & 0.12 \\ \text { J-13 } & 0 & 0.05 & 25.7 & 10.7 & 4.9 & 1.91 & 37.0 & 7.56 & 0 \\ \text { Initial } & & & & & & & & & \end{array}$

The SEM and electron microprobe analyses of reacted wafers showed no difference in the chemistry of major phenocrysts (plagioclase, sanidine and biotite) or the matrix assemblage due to hydrothermal reaction. 
However, abundant discrete calcite crystals were formed on all submerged sainiples. The calcite crystals were found to have Mg enricned cores.

Data for samples run in water saturated air at $150^{\circ} \mathrm{C}$ show similar trends to the fully submerged samples, but all reaction rates appear to be slower.

EX. ERIMENTS USING DICKSON ROCKING AUTOCLAVES

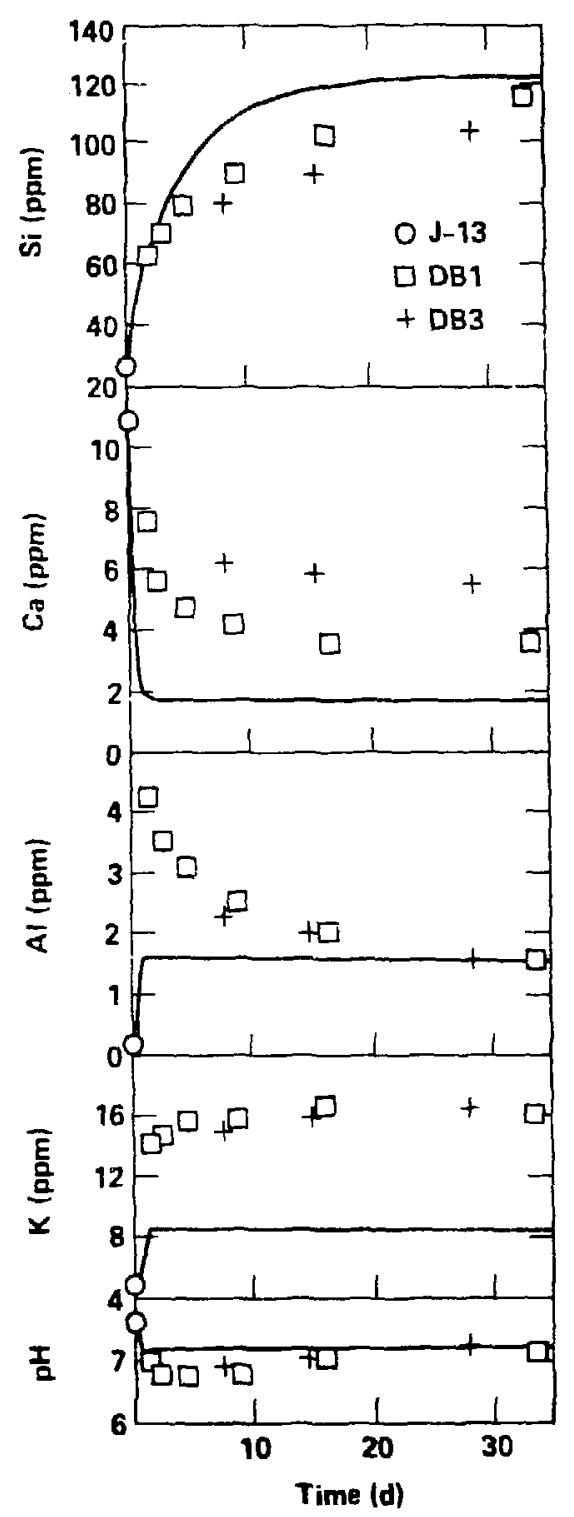

Fig. 5. Solution concentrations and pH data for Topopan Spring tuff reacted with $\mathrm{j}-13$ water at $150^{\circ} \mathrm{C}$ in Dickson-type rocking autoclaves.
In order to run experiments at temperature and pressure limits beyond those where teflon can be used and to allow samples to be taken without quenching we have run experiments in Dickson-type gold cell rocking autoclaves. These autoclaves provide a chemically inert, gas tight reaction vessel. Detailed experimental procedures are given in Knauss and Peifer [5]. Pretreated crushed Topopan Spring tuff and J-13 water were reacted at $150^{\circ} \mathrm{C}$ for 32 days in duplicate experiments.

Figure 5 shows data for Si, $\mathrm{Ca}, \mathrm{Al}, \mathrm{K}$ and $\mathrm{pH}$. Agreement between the crushed tuff results run in teflon with those run in the gold bag is excellent for $\mathrm{Si}$, Ca and $A l$, indicating that quenching is not a problem in the teflon container runs. Potassium is higher in the gold cell runs. This may be due to incomplete removal of soluble $\mathrm{K}$ during the pretreatment steps. The $\mathrm{pH}$ differs markedly between the tefion runs and the gold autoclave runs. The $\mathrm{pH}$ in autoclave runs drops initially due to carbonate precipitation and then slowly rises. The solutions remain essentially neutral for the entire test period rather than rising as seen in the teflon capsule experiments. Alkalinity remains relatively constant in the gold cells, while alkalinity in the teflon containers decreased. This suggests that $\mathrm{CO}_{2}$ is lost to the tefion and causes the change in $\mathrm{pH}$ seen in those experiments. New long term experiments in the Dickson autoclave systems are in progress and will extend for periods of up to one year.

The solution chemistry data taken as a whole shows that the changes in chemistry due to 
hydrothermal reaction between the Topopah Spring tuff and $i-13$ water are very smali expect for the dissolution of silica.

\section{EQ6 MODELS OF THE DICKSON AUTOCLAVE EXPERIMENTS}

The EQ6 computer code (1) was used to generate several kinetic reaction path models for the previcusiy described Dickson autoclave experiments. Briefly, the code provides for aqueous speciation equilibria, solubility equilioria for secondary solids, and rate laws for the dissolution of primary solids. It has no capability now to model precipitation kinetics. The user can, however, choose whicn potential secondary minerals are allowed to precipitate. The EQ6 models generated in this study differed in the set of such allowed phases.

The tuff was represented as a suite of dissolving minerals, whose surface areas were presumed proportional to their vclume percentages. The rate laws and rate constants are described elsewhere [6]. The tuff was assumed to be free of soluble salts.

All reasonable models showed that the uter becomes saturated with respect to cristobalite and, to varying degrees, supersaturated with all of the other original tuff minerals except biotite. These minerals stop dissolving upon reaching saturation. The supersaturations result from common ion effects driven by primary minerals that are still dissolving. This puts tne water in a metastable state, in which it is also supersaturated with respect to numerous potential secondary phases. The problem of finding a model that was a good match to the experiment lay largely in trying to determine which secondary phases were actually forming.

The best match was generated by model $H$, in which the allowed secondary phases were iron oxide (hematite), magnesian calcite, and gibbsite. This model is shown in the curves in Fiqure 5. It gives an excellent match to the data for $\mathrm{pH}$. It gives an equally good match in the case of magnesium (not shown in Figure $5 \%$, which drops from about $3.9 \mathrm{ppm}$ to about $0.01-0.4 \mathrm{ppm}$ after one day of reaction. It yieids results for $\mathrm{Na}$ (not shown) and $\mathrm{K}$ that are less than the experimental data. However, it appears likely that close matches nould have been obtained if the leaching pretreatment of this batch of tuff had effectively removed the soluble salt component. The predicted si concentration is somewhat high, pernaps because the model does not take into account kinetically controlled growth of quartz, a process which should be occurring because the water is supersaturated with it and it is present in the tuff as a major primary mineral. The data for $A l$ and $C a$ show a kinetically controlled approach to equiliorium assumed in the model. Encouragingly, model I (not shown on Figure 5 , the same as model $H$, but without gibosite) predicted the maximum in Al concentration within a ppm.

These results are very encouraging with respect to the question of the feasibility of this type of modeling. The inclusion of precipitation kinetics in the code will obviously lead to better kinetic models of short-term and longer experiments, and will be a necessary step to making long-term extrapolations.

\section{CONCLUSIONS}

The results from the three types of rock-water interaction tests can be summarized to show that there will be very little change in water chemistry due to interaction of vadose water with the rock on the path 
through the repository before contact with waste packages. We see no significant increase in anion concentration in the water due to interaction with the rock and there is no evidence to suggest that the readiiy soluble component found on surface outcrop samples will be present at depth. This is important because some anions such as fluoride and chloride can cause enhanced localized corrosion of canister materials. Other anions might act as complexing agents and enhance the solubility or mobility of radionuclides. The absence of a source of anions is, therefore, of assistance to the performance of the waste package. The $\mathrm{pH}$ of the solutions when runs are conducted in vessels that do not absorb $\mathrm{CO}_{2}$ remains nearly neutral. This will enhance the durability of Dorosilicate glass which shows higher dissolution-rates at $\mathrm{pH}$ less than 5 or greater than 9. The increase in silica concentration of the water as a result of reaction with the rock will also assist the durability of borosilicate glass since the dissolution rate of such glasses decreases as the silica content of the solution increases. The lack of detectable alteration of the primary mineral phases of the rock suggests that the long term behavior of the rock should be similar to that observed in the short term laboratory experiments. Finally, the success in modeling the system using a geochemical modeling code $(E Q 3 / 6)$ shows that we have sufficient understanding of the processes involved so that long term prediction of the water chemistry should be possible.

"Work performed under the auspices of the U.S. Department of Energy by the Lawrence Livermore National Laboratory under contract number W-7405-ENG-48."

This document was prepared as an account of work sponsored by an agency of the United States Government. Neither the United States Government nor the University of California nor any of their employees, makes any warranty, express or implied, or assumes any legal liability or responsibility for the accuracy, completeness, or usefulness of any information, apparatus, product, or process disclosed, or represents that its use would not infringe privately owned rights. Reference here in to any specific commercial products, process, or service by trade name, trademarn, manufacturer, or otherwise, does not necessarily constitute or imply its endorsement, recommendation, or favoring by the United States Government or the University of California. The views and opinions of authors expressed herein do not necessarily state or reflect those of the United States Government thereof, and shall not be used for advertising or product endorsement purposes.

\section{REFERENCES}

1. T. J. Wolery, Lawrence Livermore National Laboratory Report UCRL -52658 (1979).

2. V. M. Oversby, Lawrence Livermore National Laboratory Report, in preparation (1984).

3. V. M. Oversby and K. G. Knauss, Lawrence Livermore National Laboratory Report UCRL -53442 (1983).

4. K. G. Knauss and W. Beiriger, Lawrence Livermore National Laboratory hisport, in preparation (1984).

5. K. G. Knauss and D. Peifer, Lawrence Livermore National Laboratory Report, in preparation (1984).

6. T. J. Wolery and J. Delany, Lawrence Livermore National Laboratory Report, in preparation (1984). 